\title{
Whence document delivery?*
}

\author{
Judy Luther \\ President Informed Strategies
}

\section{Chair:}

David Russon, British Library Russon, Past President of ICSTI, reports on the British Library's Document Supply Service and leads this discussion of changes that are taking place in document delivery, including the demise of several important document delivery services in recent months.

Speakers:

$\begin{array}{ll}\text { R. Stephen Berry } & \text { Professor, University of Chicago } \\ & \text { The Dissemination of Results of Research: Who Should Rule? } \\ \text { Karen Hunter } & \text { Senior Vice President, Elsevier Science } \\ & \text { A New Look at ILL and Single Article Delivery } \\ \text { Randall Marcinko } & \begin{array}{l}\text { President, Marcinko Enterprises } \\ \text { Document Delivery: Will it Survive the Millenium? }\end{array}\end{array}$

\section{Whence Document Delivery}

David Russon, from the British Library and Past-President of ICSTI, moderates this session which addresses changes occurring in the area of document delivery. The British Library's document delivery service is handled on a cost-recovery basis and contributed $\$ 3$ million in revenues to publishers in the past year.

Russon describes a study conducted by six publishers and two document delivery suppliers to research the demand for articles in light of publishers' concerns that they were losing subscriptions. They were surprised to discover that $25 \%$ of requests came from subscribers and that requests typically did not exceed one or two articles per year, which is not sufficient to warrant a subscription.

Stephen Berry, a professor at the University of Chicago, points out that scientists publish in order to influence the thinking of other people rather than for direct remuneration. Berry defines publicly funded research as a public good and noted that it is in the best interest of the government to maximize the results of the research.

He encourages publishers to be inventive in their offerings to authors and suggested they create a comprehensive e-archive database that includes preprints, peer reviews, the published article, the conference proceedings, and links to all of these. Contributors would pay to put information in, and users would pay to retrieve it.

Karen Hunter, Senior Vice President with Elsevier Science, who is responsible for policy development, reflects that publishers in the print world were not able to handle document delivery and believed it was

\footnotetext{
*In cooperation with the International Council for Scientific and Technical Information.
} 
eroding subscriptions. The Copyright Law of 1976 resulted in the growth of the Copyright Clearance Center and the emergence of the CONTU guidelines which was the origin of the "rule of five". Devised by a group of publishers and librarians, the agreement was based on the idea that a library could request up to five articles from a journal through interlibrary loan; beyond that the demand would be sufficiently high to warrant purchase of that title.

Hunter observes that this is the first year that document delivery is a budgetable item for Elsevier although still very low in the $2 \%$ to $4 \%$ range. Today publishers have more of their backfiles online and could handle demand, although Elsevier is not planning to initiate a document delivery service. It's worth noting that the recent lawsuit against CARL Uncover has pointed to the need for publishers to have the full rights from the authors to the electronic version of their work.

Elsevier has been experimenting with the Peak project which provides three options: a flat fee, transaction only, or bundled access acquired beforehand for a discounted amount. The publisher is beginning to see results from this experiment, but is not ready to introduce the model that would break the boundaries of the journals to allow greater access to the articles.

Randy Marcinko, President of Marcinko Enterprises, shares his observations of changes in the industry and distinguishes three different types of suppliers. The full-service document delivery supplier has no economies of scale, since $99 \%$ of the articles are not delivered more than three times. Collection-based services, like the one offered by the British Library, are limited to supplying titles that they own and thereby eliminates some of the demand. The publishers can realize some economies of scale as they produce the title as part of the production process.

Marcinko cites an interesting statistic that more than $50 \%$ of documents are delivered in paper and that industry leaders who know the business believe it is here to stay. Electronic desktop delivery is both a benefit and a challenge, and copyright and publisher relations are going to be more important. 